\title{
State ownership and performance of firm: evidence from India
}

\author{
OMBIR SINGH, Ph.D.*
}

\author{
Article** \\ JEL: C24, C67, L32 \\ https://doi.org/10.3326/pse.43.2.4
}

\footnotetext{
* The author would like to thank the two anonymous referees for helpful comments on the paper.

${ }^{* *}$ Received: February 24, 2019

Accepted: April 29, 2019
}

Ombir SINGH

Assistant Professor, Department of Economics, Government College, Chhachhrauli, 135103 Yamuna Nagar, Haryana, India

e-mail: ombirhalwasia@gmail.com

ORCiD: 0000-0001-9051-8599 
Abstract

In this paper, an analysis of the performance of public and private sector firms operating in five different industries over the period 2011 to 2015 has been made. Using data envelopment analysis (DEA), the performance has been measured in respect of technical efficiency. To compare the performance of public and private sector firms, two distinct methodologies have been used: independent samples $t$-test and the Tobit regression model. The results of t-test indicate that the private sector has significantly higher technical efficiency in two industries but in one industry is outperformed by the public sector. In the remaining two industries, both sectors are equally efficient or inefficient. While the results of the Tobit model show that even after controlling for the firm-and industry-specific characteristics as well as the scale effect, in three industries the public sector has a managerial efficiency significantly higher than the private sector, which is found to be more efficient only in one industry.

Keywords: state ownership, performance, data envelopment analysis

\section{INTRODUCTION}

From the Second Five Year Plan (1956-1961) to the economic reforms of 1991 the public sector played a dominant role in the Indian economy and was often regarded as the engine of economic growth. However, despite its enormous contribution to the economic development of the country, the public sector had to face severe criticism due to its low profitability and under-utilization of capacity. In order to improve the performance of public sector enterprises (PSEs) by introducing competition, the Government of India (GOI) adopted the policy of de-reservation and disinvestment as a part of the economic reforms initiated in 1991. Since then, the GOI has been following the policy of privatization to increase the efficiency of PSEs, according to the belief that private ownership establishes the market for corporate control by allowing the tradability of property rights and therefore improves the quality of management. In this sequence, the GOI introduced the Competition Act in 2002 which replaced the Monopolies and Restrictive Trade Practices Act, 1969 (MRTP Act) in order to promote and sustain competition in Indian markets. The Competition Act provides enough freedom to the private sector firms to expand on a level playing field. Moreover, the doors are also opened to competition from foreign firms by extending the limits of foreign direct investment (FDI) up to 100 percent in many sectors. Opening up the economy to foreign competition has also forced a considerable restructuring of the private corporate sector via consolidation, mergers, and acquisitions as many domestic firms are now concentrating on their core competencies and exiting from unrelated and diversified fields (Dasani, 2011). It induced the free inflow of FDI along with modern cutting edge technology, which considerably increased the importance of the private sector in the Indian economy. This further fuelled competition amongst same-industry players and even in government firms.

The aim of this paper is to compare the performance of public and private sector firms in five different industrial sectors for the period from 2011 to 2015, when 
enough competition had been infused into the Indian economy. The underlying hypothesis of the present study is that (public or private) ownership does not have any significant impact on the performance (measured in terms of technical efficiency) of a firm.

The rest of the paper is structured into six sections. Section 2 presents a brief overview of the theoretical debate on the ownership and performance issue. Section 3 reviews the existing empirical literature on this issue available at national and international levels. Section 4 presents a brief outline of the methodological aspects of this study. The empirical findings are discussed in section 5 and finally, section 6 concludes.

\section{OVERVIEW OF THEORETICAL DEBATE}

Despite the existence of a large volume of theoretical and empirical literature, the question regarding the ownership and performance issue has still not been settled. The theoretical debate on this issue is based on property rights hypothesis, public choice theory, and principal-agent problem. The property rights hypothesis as propounded by Alchian (1965) and de Alessi (1980) postulates that firms in the private sector should operate with more efficiency and profitability than those in public sector. Manne (1965) and Fama (1980) argued that in the case of an efficient capital market, poor managerial performance is reflected in falling share prices, which make these firms highly vulnerable to takeover raids. Therefore, the threat of replacing the current management through takeovers serves as an effective mechanism in disciplining the current management as well as the aligning of shareholders in private firms. Since the shares of government owned firms are not tradable in the capital market, this mechanism does not work for PSEs (Sarkar, Sarkar and Bhaumik, 1998). Against this, Grossman and Hart (1980) emphasized that market failure associated with a large number of shareholders can make the functioning of the market for corporate control ineffective. For example, an individual shareholder can ignore the effect of his/her decision regarding the selling/ holding of shares on the outcome of takeover raid. If there are more chances of success of a takeover bid, he/she will prefer to hold so that he/she can participate in the profit gains resulting from the replacement of the current management with the new one (Yarrow et al., 1986).

The public choice theorists like Niskanen (1975) and Levy (1987) support the argument of the property rights hypothesis. Regardless of the market conditions, state ownership gives rise to a particular type of X-inefficiency associated with the utility maximizing behaviour of bureaucrats. They argued that the bureaucrats (the agents) are more intent on maximizing their own utility or the utility of pressure groups than on the welfare of the public (the principal). Moreover, Estrin and Perotin (1991) pointed that government attempts at accommodating the interest of various pressure groups coupled with multiple and frequently changing objectives of PSEs exacerbate the above principal-agent problem by making it more difficult to measure and monitor the outcomes of managerial efforts (Sarkar, Sarkar and Bhaumik, 1998). 
The principal-agent problem may arise in the case of privately owned big corporations due to the divorce between ownership and control. This gives rise to the problem of asymmetric information since the agents (managers) possess more information regarding the true performance of firm than the principals (the shareholders). Therefore, the agents act in their own interests rather than pursuing the interests of the principals. The principals can overcome this problem by motivating the agents through some appropriate incentives based on the outcome of managerial efforts. However, there are two major problems with this incentive-based monitoring: first, monitoring by some shareholders generates spill over benefits for others, which may lead the sub-optimal levels of monitoring (Yarrow et al., 1986). Second, if there is a risk associated with the outcome of managerial decisions and the agent is risk averse, this outcome based incentive mechanism breaks down (Shavell, 1979).

Due to the non-tradability of shares, no market for corporate control exists for PSEs. However, it does not necessarily imply the absence of managerial incentives for these enterprises. Williamson (1975) has proved that, in appropriate situations, efficient monitoring might come into effect through hierarchical arrangements in a state-owned enterprise. Moreover, government can offer profit-based incentives to efficient officials and/or fire personnel responsible for poor performance. Against the market alternative, government monitoring has two possible merits: it does not face the free-rider problem arising from the dispersed shareholdings, and it can immediately take into account the deviations between social and private returns in the goods market as well as in the factor market (Yarrow et al., 1986).

Another argument often given in favour of privatization stresses that nationalization increases the power of labour unions to extract higher wages from the government, since government officials and supervising ministries have less incentive to minimize the unit cost of labour than their private counterparts (Yarrow et al., 1986). Against this, however, it may be argued that government has more incentive to have a tough negotiating stand than its private counterparts for at least two reasons. First, government has greater resources at its disposal, which enhances its ability to face the union's pressure and resulting losses. Second, a generous settlement by the government in one area can be considered a sign of weakness by the public negotiators in other areas. If government does not take into account this demonstration effect, it may lead to more generous settlements to labour in these areas. Therefore as compared to employers in private sector, the government has a relatively high motivation to attain a reputation for toughness (Kreps and Wilson, 1982; Yarrow et al., 1986).

\section{REVIEW OF EMPIRICAL LITERATURE}

Till now, a large volume of empirical literature has grown on the ownership-performance issue and the impact of privatization. Among the most popular studies, that of Boardman and Vining (1989) examined the relative performance of the public and private sector by taking a sample of 500 non-US multinational firms 
and concluded that private sector was a superior performer to the public sector. Dewenter and Malatesta (2001) by using the data reported in Fortune magazine for a heterogeneous group of very large firms doing business around the world, compared the profitability of the public and private sector firms and found the private sector more profitable than the public sector. Further, Goldeng, Grünfeld and Benito (2008) analyzed the profitability of Norwegian firms and concluded that privately owned firms performed significantly better than the state-owned firms. Against it, Caves and Christensen (1980) and Färe, Grosskopf and Logan (1985) documented evidence of high performance by PSEs relative to private firms. By reviewing a number of other international studies, Martin and Parker (1997) found mixed evidence. Further, Thompson and Pederson (1996) analyzed the impact of the ownership structure of the 100 largest firms of several European countries. They found no indication that ownership modes systemically affect the firm's performance in terms of growth and profitability. Among more recent studies, Mijić, Jakšić and Berber (2015) compared the productivity and profitability of public and private firms operating in the Central and Eastern Europe region and found that the private sector has significantly higher profitability and productivity than that of public sector in most of the countries of the region.

As far as privatization is concerned, Megginson, Nash van Randenborgh (1994) analyzed the impact of privatization on the financial and operating performance of 61 firms belonging to 18 countries and 32 industries by comparing their performance in pre- and post-privatization period. They found that privatization significantly improved the performance of firms in terms of various parameters. Boubakri and Cosset (1998) analyzed the performance of 79 firms belonging to 21 developing economies that witnessed full and partial privatization during the period from 1980 to 1992 . Their results showed a significant increase in profitability and operating efficiency after privatization. In contrast, Qi, Wu and Zhang (2000) by taking a sample of Chinese state-owned firms, analyzed the relationship between firm performance and tradable shares and found that diffused ownership by individual domestic and foreign investors did not improve a firm's performance. On the other hand, Frydman et al. (1999), taking a sample of 218 firms from the various transition economies, found improvements in the performance of these firms in the postprivatization era, although they emphasized that improvement in performance is contingent on getting the design of privatization right. In this sequence, La Porta and Lopez-De-Silanes (1999) gave similar evidence of improvements in a firm's performance due to privatization in Mexico. Subsequently, Galal et al. (1994), Zhang, Parker and Kirkpatrick (2008), and Estrin et al. (2009) concluded that in developing countries, competition is more important than privatization for improving the performance of PSEs. On the other hand, Bartel and Harrison (2005), Megginson (2005), Tongzon and Heng (2005), and Pina and Torres (2006) concluded that the policy of privatization would be more effective in a competitive environment and therefore, suggested that both privatization and competition should go hand in hand in order to increase the efficiency of PSEs. 
In India, most of the literature on the ownership-performance issue is rather inadequate, especially in relation to the period following the Competition Act, 2002. The majority of the studies in this regard dealt with the banking sector and documented the superior performance of public sector banks as against their private counterparts following deregulation, which helped public sector banks to enhance their performance through the introduction of competition in the banking industry. The banking industry is subject to asymmetric information and moral hazard; therefore, it differs from other industrial sectors, like the manufacturing sector. Moreover, in developing countries like India, the public have a trust in government-owned financial institutions. All of these factors may be responsible for the relatively high efficiency of public sector banks in India. Only a few attempts have been made to analyze the relative performance of public and private sector firms in the non-banking industries in India. Among the earlier studies, Dholakia (1978) and Gupta (1982) investigated the performance of PSEs in the pre-reform period. They found that the performance of PSEs was improving over time. Bhaya (1990) examined the relative performance of public and private sector over the period 1982 to 1986 . He measured the performance in terms of partial labour and capital productivities and concluded that public or private ownership did not have any significant impact on performance. However, in terms of returns on investment, the private sector did better than its public counterpart. Ahluwalia (1995), taking a sample of 762 Indian firms, including 221 state owned firms and 541 large private sector companies, compared the performance of public and private sectors in terms of average gross returns on capital employed. He found the sectors do not differ significantly in terms of average gross returns. However, when the PSEs belonging to the petroleum and refinery industry were excluded from the public sector, a significant decline in the returns for public sector was observed. Further, Ramaswamy (2001) observed that PSEs were not performing as well as their private counterparts and the magnitude of private versus public sector performance increased with increasing competitive intensity. Gupta (2005), using data from 1990 to 2002 on Indian PSEs, measured the impact of partial privatization on profitability, productivity, and investment and she concluded that partial privatization has a positive impact on all of these performance indicators. One serious drawback with the above studies is that they measured the performance of the public sector in terms of profitability. It does not seem justifiable to compare public and private sector firms solely on the basis of profitability, since they are operating in different types of environment, have different types of organizational structure and different types of goals. Since both public and private sector use the scarce resources of the country, therefore, the performance must be measured and compared in terms of efficiency or productivity rather than measuring it merely in terms of profitability. Ahuja and Majumdar (1998), Majumdar (1998), and Mohan and Ray (2003) attempted to bridge this gap by measuring and comparing the performance of the public and private sector in respect of technical efficiency using DEA.

Ahuja and Majumdar (1998) assessed the DEA based efficiency of 68 PSEs working in the manufacturing sector during the period 1987 to 1991 . They found that the 
mean technical efficiency scores of these PSEs range between 0.35 and 0.39 . They suggested that privatization can improve efficiency of these PSEs. Majumdar (1999) compared the performance across four categories of firms: central government PSEs, state government PSEs (India is a federation of states), joint sector enterprises, and privately owned enterprises. The results demonstrated that private enterprises were reported highly efficient followed by joint sector enterprises and the enterprises owned by centre or state government. However, in these studies, performance was measured across highly heterogeneous samples of firms belonging to diverse industrial sectors and therefore they clubbed together firms with widely differing technologies. A meaningful comparison of performance and efficiency through DEA requires at least a modest degree of homogeneity among the decisionmaking units being compared. Keeping in view the problem of lumping together the data of heterogeneous firms, Mohan and Ray (2003) investigated the relative efficiency of the public and the private sector using firm level data for the period 1992 to 1999. They found that in five out of eight industries, handing over public sector firms to private ownership will not make any significant improvements in efficiency.

All of these studies belong to the pre-reform period or the period when economic reforms were just initiated. In the pre-reform period, the public sector was a dominant player in the Indian industrial sector and faced negligible competition from the private sector. The most recent studies on the ownership and performance issue have been conducted by Kaur and Kumar (2010), Gupta, Jain and Yadav (2011) and Jain (2017). Kaur and Kumar (2010) compared the technical efficiency of foreign, private, and public sector pharmaceutical firms in the Indian context. They found that foreign owned firms perform more efficiently than domestic firms and the private sector firms perform more efficiently than PSEs. They regarded the difference in the technologies used by these firms as the main reason for performance differentials. Gupta, Jain and Yadav (2011) analyzed the financial performance of disinvested central PSEs in India on pre and post disinvestment basis over the period, 1986-87 to 2009-10. The authors observed a significant decline in the performance of PSEs measured in terms of profitability and major efficiency ratios after disinvestment and suggested that partial disinvestment was not a successful measure for improving the financial performance of the PSEs across various industrial sectors. By using stochastic frontier analysis, Jain (2017) measured the performance of 238 central PSEs (belonging to various sectors) for the period 1991 to 2010. She found a strong and positive relationship between disinvestment and efficiency of PSEs.

Against this background, the present study differs from the previous studies in two respects. First, it tries to measure the relative performance of the public and private sector in today's competitive environment. Second, unlike the previous studies using firm level data, it avoids the problem of lumping together disparate industrial categories. The efficiency of a firm belonging to a particular industry must be analyzed against an efficient production frontier estimated from the observed input-output data of firms from that industry only. It provides a more 
meaningful measure of technical efficiency by controlling for technological heterogeneity across varied industrial sectors (Mohan and Ray, 2003).

\section{METHODOLOGY}

\subsection{SAMPLE AND DATA}

For the purpose of the present study, five industries viz. engineering goods, fertilizers, mining/minerals, refineries, power generation \& supply; have been identified, in which both public and private sectors have a massive presence. From each industry, a sample of ten or more firms having at least a 50 percent share (or above) in the total sales of their respective industries, has been selected. The study is based on firm-level data and covers a period of five years from 2011 to 2015. The detailed data on profit-loss accounts and balance sheets have been obtained from Capitaline database. Table 1 shows percentage share of selected firms in total sales of their respective industries.

\section{TABle 1}

Percentage share of selected firms in total sales of industry in 2015

Selected industry No. of selected firms Percentage share in industry's sales

\begin{tabular}{lll}
\hline Engineering goods & 18 \\
\hline Fertilizers & 12 \\
\hline Mining/minerals & 15 \\
\hline Refineries & 10 \\
\hline Powergeneration \& supply & 17
\end{tabular}

Source: Capitaline database.

\subsection{DATA ENVELOPMENT ANALYSIS}

This is a linear programming technique, initially developed by Charnes, Cooper and Rhodes (CCR) (1978) and further generalized by Banker, Charnes and Cooper (BCC) (1984), to evaluate the efficiency of a homogeneous set of decision-making units. An input-orientated version of DEA (where the objective is to minimize inputs for a given level of output) with the assumption of constant returns to scale (CRS), proceeds by solving a sequence of linear programming problems:

Minimize $E_{n}$, subject to:

$$
\begin{gathered}
\sum_{j=1}^{N} w_{j} y_{i j}-y_{i n} \geq 0 i=1, \ldots, I \\
\sum_{j=1}^{N} w_{j} x_{k j}-E_{n} x_{k n} \leq 0 k=1, \ldots, K \\
w_{j} \geq 0 j=1, \ldots, N
\end{gathered}
$$

where there are $N$ organizations in the sample producing $i$ different outputs (y) and using $K$ different inputs (x). The $w_{j}$ are weights applied across the $N$ organizations. $E_{n}$ is the ratio of weighted sum of inputs to the weighted sum of outputs of the $n t h$ 
organization. If we impose an additional constraint that the weights must sum to

one (i.e. $\sum_{j=1}^{N} w_{j}=1$ ), the above DEA model becomes a variable returns to scale (VRS) model. It allows for the existence of economies and diseconomies of scale. The estimation of technical efficiency with CRS and VRS assumptions allows the overall technical efficiency (OTE) to be decomposed into two collectively exhaustive components: pure technical efficiency (PTE) and scale efficiency (SE), i.e. $O T E=P T \times S E$ (Singh and Bansal, 2017). PTE is also known as managerial efficiency. Further, an independent samples t-test is used in order to compare the efficiency score of public and private sector firms.

\subsection{INPUT-OUTPUT SPECIFICATION}

For specifying the input and output variables, the present study follows the approach adopted by Mohan and Ray (2003). Energy, raw material, wages, and capital are used as inputs. Since energy and raw materials are used as inputs, the use of gross output, rather than net value added (NVA), is appropriate. Using NVA as output is suitable only when labour and capital are considered as inputs. Net sales of firms (i.e. sales net of excise duties) adjusted for changes in inventories are used as gross output. Instead of using the gross or fixed assets, the summation of two items, interest and depreciation is used as capital that is based on flows (not on stocks) like other measures for output and inputs. All nominal values have been appropriately deflated.

\subsection{TOBIT MODEL}

In order to examine the impact of ownership on the technical efficiency of selected firms in our sample, a second stage analysis of the technical efficiency scores obtained in stage one is performed by applying the Tobit regression model. Since the dependent variable efficiency score is bounded between 0 and 1, an appropriate theoretical specification is Tobit model with two side censoring (Sufian and Abdul Majid, 2008):

$Y_{i t}=\alpha_{0}+\alpha_{1} C L_{i t}+\alpha_{2}$ Size $_{i t}+\alpha_{3} H_{t}+\alpha_{4} P u b+\sum_{j=2}^{5} \beta_{j}$ Ind $_{j}+\sum_{j=2}^{5} \gamma_{j}\left(\right.$ Ind $\left._{j} P u b\right)+\sum_{t=12}^{15} \delta_{t} T_{t}+u_{i t}$

where $Y_{i t}=$ technical efficiency scores of firm $i$, in year $t, C L_{i t}=$ capital-labour ratio (measured as the ratio of fixed capital to employee cost) of firm $i$ in year $t$, Size $_{i t}=$ share of firm $i$ in industry's total sales in year $t, H_{t}=$ Herfindahl index in year $t, P u b=1$ if firm belongs to public sector and zero otherwise, $I n d_{j}=1$ if firm belongs to industries $j$ and zero otherwise (industry code 1 is assigned to the engineering goods industry which is used as the reference industry) and $T=1$ if observation is from year $t$ and zero otherwise (year 2011 is used as the reference year). It is worth mentioning that the impact of ownership on the technical efficiency of a firm in the engineering goods industry cannot be measured by the above specification of the model. In order to measure the impact of ownership in this sector, the above model is re-estimated assuming the Fertilizers sector as the reference industry. The results for other industries are fairly similar to the findings of the previous models. Therefore, they are not reported in this study. 
Table 2 presents the principal characteristics of selected public and private firms. The table shows that two industries (viz. refineries and power generation \& supply) are characterized by government monopoly, as state owned firms in these two industries, on average, cover 76.57 and 68.29 percent of industry's total sales respectively over the period of time. In the other three industries (i.e. engineering goods, fertilizers, and mining/minerals) the private sector has the largest part of (approximately 70 percent) of the industry's total sales over the period under consideration. The percentage share of selected firms in industry's total assets and employee cost demonstrates that public sector firms are relatively labour intensive whereas private sector firms are relatively capital intensive. Further, the Herfindahl index and the concentration ratio measure the extent of competition in each of the industries. A relatively low value of these two indices in an industry indicates a high degree of competition in that industry. The degree of competition is highest in the power generation \& supply industry followed by engineering goods and fertilizers industries. As far as mining/minerals and refinery industries are concerned, the competition is lowest in these two industries.

\section{TABle 2}

Principal characteristics of selected public and private sector firms, 2011 to 2015

\begin{tabular}{|c|c|c|c|c|c|c|c|c|}
\hline \multirow[t]{2}{*}{ Industry } & \multicolumn{2}{|c|}{$\begin{array}{c}\text { Percentage } \\
\text { share in } \\
\text { industry's sales }\end{array}$} & \multicolumn{2}{|c|}{$\begin{array}{c}\text { Percentage } \\
\text { share in } \\
\text { industry's total } \\
\text { assets }\end{array}$} & \multicolumn{2}{|c|}{$\begin{array}{c}\text { Percentage } \\
\text { share in } \\
\text { industry's } \\
\text { employee cost }\end{array}$} & \multirow[t]{2}{*}{$\begin{array}{l}\text { Herfind- } \\
\text { ahl } \\
\text { Index } \\
(\mathrm{H})^{1}\end{array}$} & \multirow[t]{2}{*}{$\begin{array}{c}\text { Concentra- } \\
\text { tion Ratio } \\
(\mathrm{CR})^{2}\end{array}$} \\
\hline & Public & Private & Public & Private & Public & Private & & \\
\hline Engineering & 25.31 & 74.09 & 21.22 & 78.46 & 24.54 & 75.06 & 0.12 & 56.60 \\
\hline Fertilizers & 29.76 & 67.73 & 19.16 & 72.73 & 46.58 & 49.98 & 0.10 & 50.62 \\
\hline Refineries & 76.57 & 23.42 & 68.33 & 32.04 & 78.25 & 21.74 & 0.19 & 83.09 \\
\hline Mining/minerals & 22.10 & 77.89 & 23.68 & 76.31 & 62.73 & 37.26 & 0.45 & 86.99 \\
\hline Power & 68.29 & 31.70 & 71.87 & 28.12 & 74.76 & 25.23 & 0.05 & 33.51 \\
\hline
\end{tabular}

Note: the figures in the table are the averages of the period from 2011 to 2015.

Source: author's calculation.

Table 3 shows the descriptive statistics of the efficiency score of selected public and private sector firms for the period 2011 to 2015. The mean OTE scores of engineering goods, refineries, and power generation \& supply industries are increasing over time. This is because in these industries, both public and private sector firms have improved their performance over time, as indicated by the increased value of their mean OTE scores in 2015 compared to that of 2011. However, this improvement is more consistent for the private sector, as revealed by the decreased values of standard deviation in 2015 for each of the three industries. In the fertilizers and mining industries, the average efficiency score is declining over time at the industry level. In the fertilizers industry, the mean OTE scores of both

\footnotetext{
${ }^{1} H=\sum_{i}^{n} S_{i}^{2}$ and $\frac{1}{n} \leq H \leq 1$, where $S_{i}$ is the ratio of firm ith sales to that of industry.

${ }^{2} \mathrm{CR}=$ percentage share of the largest four firms in industry's total sales.
} 
sectors have declined marginally over the period. However, the value of standard deviation for the public sector has increased substantially relative to that of the private sector which implies that the problem of declining efficiency is more serious in the public sector. As far as the mining industry is concerned, the mean OTE score of private sector firms is fairly stable over time, though it is in decline in the case of PSEs. If the standard deviation is considered, it can be seen that its value has decreased considerably for the public sector and increased for the private sector over the period. This implies that the OTE score of an average PSE concentrates to the sectoral mean over the period of time, whereas the opposite is true in case of private sector firms.

\section{TABLE 3}

Descriptive statistics of overall technical efficiency (OTE), 2011 to 2015

\begin{tabular}{|c|c|c|c|c|c|c|c|c|c|}
\hline \multirow[t]{2}{*}{ Industry } & \multirow[t]{2}{*}{ Year } & \multicolumn{3}{|c|}{ Mean OTE } & \multicolumn{3}{|c|}{ Standard deviation } & \multicolumn{2}{|c|}{ Range } \\
\hline & & Public & Private & Industry & Public & Private & Industry & Public & Private \\
\hline \multirow{2}{*}{$\begin{array}{l}\text { Engineering } \\
\text { goods }\end{array}$} & 2011 & 0.909 & 0.964 & 0.937 & 0.085 & 0.037 & 0.071 & 0.260 & 0.131 \\
\hline & 2015 & 0.913 & 0.973 & 0.943 & 0.094 & 0.035 & 0.077 & 0.304 & 0.108 \\
\hline \multirow{2}{*}{ Fertilizers } & 2011 & 0.920 & 0.976 & 0.995 & 0.066 & 0.033 & 0.055 & 0.169 & 0.111 \\
\hline & 2015 & 0.905 & 0.963 & 0.941 & 0.226 & 0.040 & 0.142 & 0.900 & 0.127 \\
\hline \multirow{2}{*}{$\begin{array}{l}\text { Mining/ } \\
\text { minerals }\end{array}$} & 2011 & 0.759 & 0.739 & 0.749 & 0.296 & 0.177 & 0.241 & 0.839 & 0.437 \\
\hline & 2015 & 0.719 & 0.744 & 0.732 & 0.165 & 0.297 & 0.237 & 0.848 & 0.541 \\
\hline \multirow{2}{*}{ Refineries } & 2011 & 0.896 & 0.687 & 0.792 & 0.090 & 0.391 & 0.280 & 0.260 & 0.686 \\
\hline & 2015 & 0.888 & 0.828 & 0.858 & 0.092 & 0.214 & 0.166 & 0.247 & 0.619 \\
\hline \multirow{2}{*}{$\begin{array}{l}\text { Power } \\
\text { generation } \\
\& \text { supply }\end{array}$} & 2011 & 0.673 & 0.713 & 0.693 & 0.247 & 0.357 & 0.304 & 0.676 & 0.657 \\
\hline & 2015 & 0.789 & 0.823 & 0.806 & 0.247 & 0.170 & 0.167 & 0.499 & 0.588 \\
\hline
\end{tabular}

Source: author's calculation.

\subsection{RESULTS OF INDEPENDENT SAMPLES T TEST}

Table 4 compares the average technical efficiency of public and private sector firms in five different industries from 2011 to 2015. The table demonstrates that out of five, in two industries (i.e. engineering goods and fertilizers) the OTE of private sector companies is significantly greater than that of PSEs over the period. In the engineering goods sector, the mean OTE score of private firms exceeds the mean OTE score of their public counterparts by as much as 5.8 percentage points, whereas in the case of the fertilizers industry, the mean OTE score of private sector firms is significantly greater than that of the PSEs by 5.7 percentage points. In order to find out the sources of this inefficiency, one must investigate the PTE and SE scores of the decision making units under consideration. In both industries, PSEs have a significantly low PTE score as compared with their private counterparts, which indicates the presence of managerial inefficiency in the operation of PSEs in these two industries. As far as scale efficiency is concerned, both public and private sector firms are reported equally efficient over the period of time in both industries. Therefore the main reason for inefficiency in the operations of PSEs may be attributed to managerial inefficiency rather than to inefficiency caused by scale factors. The PTE relates to the capability of managers to utilize a 
firm's given resources, whereas the SE refers to exploiting scale economies by operating at a point where the production frontier exhibits constant returns to scale (Sufian and Habibullah, 2009). It is noteworthy that in both of these two industries (i.e. engineering goods and fertilizers), the degree of competition is relatively high in the context of the industries under consideration. This implies that when the policy of privatization is carried out together with increased competition, privatization will certainly result in improvements in efficiency (Ramaswamy, 2001; Megginson, 2005).

In the case of the mining/minerals sector, no significant difference has been observed in the performance of public and private sector firms as far as OTE is concerned. On an average, both sectors are reported with approximately 25 percent inefficiency. Since efficiency is measured using an input-oriented DEA model, which implies that an average firm in mining/minerals industry if producing its output on the efficient frontier instead of its current location would need only 75 percent of the inputs currently being used; by adopting best practice technology, firms, on average, can reduce their inputs by at least 25 percent. However, sources of inefficiency differ in the two sectors as indicated by their PTE and SE scores in table 4 . The mean PTE score $(0.852)$ of private sector firms is significantly lower than that $(0.949)$ of the public sector, by 0.098 , for the period under consideration. Therefore, it is evident that with respect to the efficient use of inputs, PSEs outperform their private counterparts. As far as SE is concerned, private sector firms exhibit a significant lead over their public counterparts. This implies that private sector firms are operating closer to the minimum point of their long-run average cost curve than their public counterparts. Therefore, the lead of the PSEs in efficient use of inputs is completely offset by their inefficiency in realizing economies of scale as compared to private sector firms, which, as a result, renders the differences between the performances of these two categories of firms statistically insignificant as far as OTE is concerned. Further, the degree of concentration is very high in the mining/mineral industry (as indicated by the Herfindahl index and concentration ratio in table 2). This lack of competition may be regarded as a potential source of technical inefficiency in the operations of both public and private firms in this industry, which consequently renders the difference between the OTE of these two sectors statistically insignificant. From the Hicksian perspective, the monopolistic structure of the market results in loss of efficiency by enabling firms to charge prices above the marginal cost and to produce less than the optimal level (Dudu and Kilicaslan, 2009). 
TABLE 4

Average technical efficiency of public and private sector firms, 2011 to 2015

\begin{tabular}{|c|c|c|c|c|}
\hline \multirow[t]{2}{*}{ Industry } & & \multicolumn{3}{|c|}{ Average sectoral technical efficiency } \\
\hline & & OTE & PTE & SE \\
\hline \multirow{3}{*}{ Engineering goods } & Private sector & 0.969 & 0.994 & 0.975 \\
\hline & Public sector & 0.911 & 0.934 & 0.976 \\
\hline & Mean difference & $0.058 * *$ & $0.06 * *$ & -0.001 \\
\hline \multirow{3}{*}{ Fertilizers } & Private sector & 0.97 & 0.989 & 0.981 \\
\hline & Public sector & 0.912 & 0.964 & 0.978 \\
\hline & Mean difference & $0.057 * *$ & $0.025 * *$ & 0.002 \\
\hline \multirow{3}{*}{ Mining/minerals } & Private sector & 0.751 & 0.852 & 0.889 \\
\hline & Public sector & 0.729 & 0.949 & 0.777 \\
\hline & Mean difference & 0.022 & $-0.098 * *$ & $0.112 * *$ \\
\hline \multirow{3}{*}{ Refineries } & Private sector & 0.758 & 0.956 & 0.799 \\
\hline & Public sector & 0.892 & 0.992 & 0.899 \\
\hline & Mean difference & $-0.135 * *$ & $-0.036 * *$ & $-0.1 * *$ \\
\hline \multirow{3}{*}{$\begin{array}{l}\text { Power generation } \\
\& \text { supply }\end{array}$} & Private sector & 0.768 & 0.907 & 0.851 \\
\hline & Public sector & 0.731 & 0.912 & 0.794 \\
\hline & Mean difference & 0.037 & -0.005 & 0.057 \\
\hline
\end{tabular}

$* * *, * *$, and $*$ significant at $1 \%, 5 \%$ and $10 \%$ level, respectively.

Source: author's calculation.

In refineries, the mean OTE score of PSEs as a group is 0.892 and in the case of private sector firms, it is 0.758 , which is significantly lower than that of publicly owned firms. However, as compared to the benchmark, public and private sector firms are observed with 11 and 24 percent inefficiencies over the period of time. The superior performance of the public sector is attributable to both managerial and scale factors. The mean PTE score of PSEs is significantly greater than that of private firms by 3.6 percentage point, which indicates a relatively high managerial efficiency of the public sector in the use of available inputs. As far as scale efficiency is concerned, the mean SE score in the public sector significantly exceeds the mean score of their private counterparts by 10 percentage points. This implies that PSEs are operating closer to the optimal level of scale than the privately owned firms in refinery sector. The superior performance of the public sector in this industry may be due to the fact that the public sector has enjoyed a monopoly for a long period of time in this industry. Moreover, in India the refinery industry has been a subject of price control for a long period of time, which constrained the entry of private firms into this industry by making it less profitable for the private sector.

Further, table 4 demonstrates that in the power generation \& supply industry, the mean OTE score of private sector firms for the period of study is 0.768 , which is slightly greater than that of PSEs by 0.037 ; however, the difference is statistically insignificant. Another thing which can be observed is that the mean OTE scores of both public and private sector firms are significantly low as compared to the benchmark. In the case of PSEs, on an average, 26.9 percent inefficiency is present over the period of time under consideration. In the case of private sector 
firms, the size of inefficiency is approximately 23.2 percent. As indicated by their PTE and SE scores, both managerial and scale factors contribute significantly to the overall inefficiency in the two sectors. The average size of managerial inefficiencies in the operation of public sector firms is 8.8 percent, while in the case of private sector firms it is 9.3 percent. Therefore, with respect to the efficient use of inputs, firms in the two sectors are equally efficient or inefficient. As far as scale inefficiency is concerned, 14.9 percent scale inefficiency exists in the production process of private firms, while in the case of PSEs; the average size of scale inefficiency is 20.6 percent. Therefore, as with managerial efficiency, both sectors are equally scale efficient or inefficient in the power sector. It is important to note that like refineries, in the power industry the market power is concentrated in favour of the public sector. Apart from this, in India the prices of electricity are regulated by the government instead of by market forces. Therefore, both government monopoly and regulation may be regarded as a possible source of the inefficiency present in the power sector as a whole.

\subsection{RESULTS OF TOBIT REGRESSION MODEL}

In order to corroborate the findings of the previous section, this section tries to investigate the impact of ownership on the various estimates of technical efficiency (viz. OTE, PTE and SE) of firms by using the Tobit regression model. The regression analysis by controlling the firm- and industry-specific characteristics provides a more robust analysis of the relative performance of state owned and privately owned firms. For this purpose, we have run three regressions taking OTE, PTE and SE as dependent variables and dummy variables for ownership, industry, industry interacting with ownership, and time as the independent variables. Apart from this, the size of a firm (which is measured in terms of its share in total sales of industry), capital-labour ratio, and Herfindahl Index (which is used as the proxy of monopoly position of the market) are used as additional control variables. All of these variables reflect firm- and industry-specific characteristics that might affect the efficiency of firms, apart from the ownership structure.

Table 5 demonstrates that all of the coefficients $\left(\delta_{i}\right)$ of the time dummies in all of the three regression models are statistically insignificant, which implies that time does not have any significant impact on the overall efficiency or on the managerial and scale efficiency of a firm. The results also show that the capital-labour (CL) ratio has significant and negative impacts on OTE as well as PTE. However, its impact on SE is found to be statistically insignificant. Since PTE and SE are the collectively exhaustive components of OTE, it is evident that the CL ratio is affecting the OTE through PTE. The negative impact of the capital-labour ratio on efficiency implies that either labour is more productive than capital (as in case of labour-augmenting technological progress) or Indian firms are using capital beyond the optimal level (as in the case of the existence of excess capacity). Whatever the case, if these firms substitute labour for capital, i.e. use capital saving techniques of production, it will increase their productive efficiency. Further it is found that the size of a firm has a significant and positive impact on OTE and PTE. 
As far as SE is concerned, the impact of size is reported insignificant. Therefore, as with the CL ratio, the size of a firm affects OTE through PTE. From a Schumpeterian perspective, a positive impact of size on efficiency indicates that a large firm has a higher tendency to make product and process innovations which increase its productive efficiency. Further, the monopolistic structure of a market (as measured by the Hefindahl Index) has a significantly negative impact on PTE which implies that the monopolistic structure of the market reduces the managerial incentives to produce at the minimum cost since the firms can charge the prices above the marginal cost and therefore, can survive in the economy in spite of their higher costs.

The interaction coefficients $\left(\gamma_{\mathrm{j}}\right)$ measure the impact of ownership on the performance of firms in a particular industry. Table 5 shows that the interaction coefficient $\left(\boldsymbol{\gamma}_{\mathrm{j}}\right)$ is statistically significant only for the refinery industry if we consider OTE as the dependent variable. This means that even after controlling for the impact of firm and industry specific characteristics, state ownership has a positive impact on the OTE of a firm in the refinery sector while in case of the remaining four industries (viz. engineering goods, fertilizers, mining/minerals, and power), ownership does not matter. Further, table 5 shows that in the case of four industries (viz. engineering goods, mining/minerals, refineries, and power), public ownership has a significant impact on PTE, i.e. the efficiency of management in the utilization of available inputs, as indicated by the highly significant interaction coefficients $\left(\gamma_{\mathrm{j}}\right)$ for these industries. In the case of the engineering goods sector, state ownership has a negative impact on the managerial efficiency of PSEs, i.e. PSEs suffer from managerial underperformance. Thus, privatizing these firms will certainly improve their managerial performance in this industry. However, in the case of mining, refineries, and power, state ownership has a positive impact on managerial performance. This implies that even if we remove the scale effect, transferring the ownership of PSEs to private sector will reduce the managerial efficiency of PSEs in these three industries. Therefore, like those of Mohan and Ray (2003), our results reject the argument that the performance of private sector would be superior to that of public sector once we adjusted for the scale effect. As far as SE is concerned, state ownership has significant effect on SE in only two industries, i.e. refineries and power generation \& supply. In the case of refineries, the public sector has advantage of scale, while it is operating with diseconomies of scale in power sector. It is worth mentioning that the results of the Tobit model are somewhat different from the results of the independent samples t-test, in that, as per Tobit model, the public sector is reported as being marginally superior to the private sector in terms of both OTE and PTE. This may happen due to the difference in the nature of two methodologies. Unlike the t-test, regression analysis controls the effect of other explanatory variables by including them in the model as additional control variables. 
TABle 5

Tobit regression estimates

\begin{tabular}{|c|c|c|c|}
\hline \multirow{2}{*}{$\begin{array}{l}\text { Explanatory } \\
\text { variables }\end{array}$} & \multicolumn{3}{|c|}{ Dependent variable } \\
\hline & OTE & PTE & SE \\
\hline Const $\left(\alpha_{0}\right)$ & $1.04993 * * *$ & $1.40393 * * *$ & $1.06753 * * *$ \\
\hline $\operatorname{CL}\left(\alpha_{1}\right)$ & $-1.194 \mathrm{e}-05^{* * *}$ & $-2.476 \mathrm{e}-05^{* * *}$ & $3.473 \mathrm{e}-06$ \\
\hline Size $\left(\alpha_{2}\right)$ & $0.166651^{* *}$ & $0.634850 * * *$ & -0.117076 \\
\hline $\mathrm{H}\left(\alpha_{3}\right)$ & -0.419001 & $-1.17132 * *$ & 0.0588547 \\
\hline $\operatorname{Pub}\left(\alpha_{4}\right)$ & $-0.0545116^{* * *}$ & $-0.181944 * * *$ & -0.0290541 \\
\hline $\operatorname{Ind}_{2}\left(\beta_{2}\right)$ & -0.0284189 & $-0.147134 * *$ & 0.0163939 \\
\hline $\operatorname{Ind}_{3}\left(\beta_{3}\right)$ & $-0.215366^{* * *}$ & $-0.300554 * * *$ & $-0.136254 * * *$ \\
\hline $\operatorname{Ind}_{4}\left(\beta_{4}\right)$ & $-0.193480 * * *$ & -0.0446409 & $-0.218155^{* * *}$ \\
\hline $\operatorname{Ind}_{5}\left(\beta_{5}\right)$ & $-0.0914068^{* *}$ & -0.120872 & $-0.0859020^{*}$ \\
\hline $\operatorname{Ind}_{1} \operatorname{Pub}\left(\gamma_{1}\right)$ & 0.0172838 & $-0.073493 * *$ & 0.00322398 \\
\hline $\operatorname{Ind}_{2} \operatorname{Pub}\left(\gamma_{2}\right)$ & -0.00686827 & 0.0734939 & -0.00322398 \\
\hline $\mathrm{Ind}_{3} \mathrm{Pub}\left(\gamma_{3}\right)$ & 0.0343362 & 0.387319 *** & -0.0870903 \\
\hline $\operatorname{Ind}_{4} \mathrm{Pub}\left(\gamma_{4}\right)$ & 0.167070 *** & $0.159962 * *$ & $0.133120 * *$ \\
\hline $\operatorname{Ind}_{5} \operatorname{Pub}\left(\gamma_{5}\right)$ & -0.0611306 & $0.195389 * *$ & $-0.127205^{* *}$ \\
\hline $\mathrm{T}_{12}\left(\delta_{12}\right)$ & -0.0318665 & -0.0345488 & -0.0138445 \\
\hline $\mathrm{T}_{13}\left(\delta_{13}\right)$ & 0.0149875 & -0.0358358 & 0.0193831 \\
\hline $\mathrm{T}_{14}\left(\delta_{14}\right)$ & 0.0275370 & -0.0141005 & 0.0304489 \\
\hline $\mathrm{T}_{15}\left(\delta_{15}\right)$ & 0.00427809 & -0.0198059 & 0.00490746 \\
\hline Sigma & $0.180388^{* * *}$ & $0.184465^{* *}$ & $0.213104 * *$ \\
\hline
\end{tabular}

$* * *, * *$, and $*$ significant at $1 \%, 5 \%$ and $10 \%$ level, respectively.

Source: authors' calculation.

The relatively high managerial efficiency of state owned firms may be attributed to the fact that most of the PSEs in our sample belongs to the Maharatna and Navratna categories. As the part of economic reforms initiated in 1991, the GOI gradually closed or sold off sick PSEs to the private sector. Profit-making PSEs were classified as Maharatna, Navratna and Miniratna PSEs based on their performance. These PSEs have been given substantially enhanced autonomy and operational freedom, which significantly increases their efficiency. Further, continuously increasing competition from both domestic and foreign firms in the post reform period also helped these PSEs in improving their efficiency. Moreover, it may be possible that underlying structural factors, such as poor governance, weak law enforcement and tardy bankruptcy procedures tend to keep the private sector from realizing its fullest potential (Mohan and Ray, 2003).

\section{CONCLUSION}

In this paper, an analysis of the performance of public and private sector firms operating in five different industries has been made over the period 2011 to 2015. Using DEA, the performance has been measured in terms of technical efficiency. In order to compare the technical efficiency of public and private sector enterprises, two distinct methodologies, the independent samples t-test and the Tobit regression model, have been used. The main findings of the study may be summarized as 
follows. First, the results of t-test indicate that out of five, the private sector has significantly high OTE as well as PTE in two industries, engineering goods and fertilizers, where competition is relatively high. In contrast, in refineries where market power is concentrated to the public sector, PSEs have considerably higher OTE and PTE as well as SE than their private counterparts. Therefore it may be concluded that competition along with privatization plays a positive role in improving the efficiency of firms. Second, the results of the Tobit model reveal that even after controlling for the effect of firm specific characteristics and that of the monopolistic structure of the market, the public sector emerges as a superior performer in respect of OTE in the refinery industry. In rest of the four industries, ownership does not matter. Third, if we consider the argument that PSEs enjoy the advantages of scale and compare their performance with that of their private counterparts only in terms of PTE, the public sector emerges as a superior performer in three industries (mining/minerals, refineries, and power generation \& supply). Against this, the private sector has significantly high PTE only in engineering goods industry. This implies that only in one industry out of five, transferring ownership to the private sector would result in efficiency gains, even if we disregarded the scale effect. In three industries, privatization would result in a loss of managerial efficiency. In the case of the remaining two industries, no firm conclusion can be made regarding the impact of public or private ownership.

The effectiveness of privatization is based on the link between the market for corporate control and enterprise performance. Considerable information poverty among shareholders and potential raiders regarding the true performance of a firm coupled with the high transaction costs of takeovers due to the time consuming process of transferring shares between sellers and buyers, and stringent takeover regulations can weaken this link in developing countries like India (Sarkar, Sarkar and Bhaumik, 1998). Thus, the policy of privatization cannot effectively increase the efficiency of private sector firms in these countries. The positive impact of privatization on economic performance can take place only in an appropriate institutional environment with relevant legal standards, i.e. protection of shareholders and creditors, righteous and enforceable contracts, functioning bankruptcy courts, adequate banking system, capital market supervision, and so on (Tichá, 2012).

\section{Disclosure statement}

No potential conflict of interest was reported by the author. 
Table A1

List of the selected public and private sector firms

Industry

Firm

Ownership status

\begin{tabular}{|c|c|c|}
\hline \multirow{18}{*}{$\begin{array}{l}\text { Engineering } \\
\text { goods }\end{array}$} & B HEL & Public \\
\hline & BEML Ltd & Public \\
\hline & Bharat Dynamics Ltd & Public \\
\hline & Engineers India Ltd & Public \\
\hline & Hindustan Aeronautics Ltd & Public \\
\hline & Larsen \& Toubro Ltd & Private \\
\hline & Siemens Ltd & Private \\
\hline & Tata Projects Ltd & Private \\
\hline & CG Power \& Industrial Solution Ltd & Private \\
\hline & Crompton Greaves Ltd & Private \\
\hline & Thermax Ltd & Private \\
\hline & BGR Energy Systems Ltd & Private \\
\hline & Tata Hitachi Construction Machinery Company Pvt Ltd & Private \\
\hline & IL\&FS Transportation Networks Ltd & Private \\
\hline & L\&T Technology Services Ltd & Private \\
\hline & ISGEC Heavy Engineering Ltd & Private \\
\hline & Sunil Hitech Engineers Ltd & Private \\
\hline & Ashoka Buildcon Ltd & Private \\
\hline \multirow{12}{*}{ Fertilizers } & Nation Fertilizers Ltd & Public \\
\hline & Rashtriya Chemicals \& Fertilizers Ltd & Public \\
\hline & Madras Fertilizers Ltd & Public \\
\hline & Fertilisers \& Chemicals Travancore Ltd & Public \\
\hline & Coromandel International Ltd & Private \\
\hline & Chambal Fertilizers \& Chemical Ltd & Private \\
\hline & Gujarat State Fertilizers \& Chemical Ltd & Private \\
\hline & Gujarat Narmada Valley Fertilizers \& Chemical Ltd & Private \\
\hline & Zuari Agro Chemicals Ltd & Private \\
\hline & Nagarjuna Fertilizers \& Chemical Ltd & Private \\
\hline & Deepak Fertilizers \& Petrochemicals Corp. Ltd & Private \\
\hline & Mangalore Chemicals \& Fertilizers Ltd & Private \\
\hline
\end{tabular}




\begin{tabular}{|c|c|c|}
\hline & & \\
\hline & Coal India Ltd & Public \\
\hline & Gujarat Mineral Development Corp. Ltd & Public \\
\hline & MOIL Ltd & Public \\
\hline & NMDC Ltd & Public \\
\hline & 20 Microns Ltd & Private \\
\hline & Associated Stone Industries Ltd & Private \\
\hline & Facor Alloys Ltd & Private \\
\hline & Ferro Alloys Corporation Ltd & Private \\
\hline & Indian Metals \& Ferro Alloys Ltd & Private \\
\hline & Indsil Hydro Power \& Manganese Ltd & Private \\
\hline & Maithan Alloys Ltd & Private \\
\hline & Rohit Ferro Tech Ltd & Private \\
\hline & Sandur Manganese \& Iron Ores Ltd & Private \\
\hline & Shirpur Gold Refinery Ltd & Private \\
\hline & Vedanta Ltd & Private \\
\hline \multirow{10}{*}{ Refineries } & Bharat Petroleum Corporation Ltd & Public \\
\hline & Bharat Oman Refinery Ltd & Public \\
\hline & Chennai Petroleum Corporation Ltd & Public \\
\hline & Hindustan Petroleum Corporation Ltd & Public \\
\hline & Indian Oil Corporation Ltd & Public \\
\hline & Mangalore Refinery \& Petrochemicals Ltd & Public \\
\hline & Numaligarh Refinery Ltd & Public \\
\hline & Essar Oil Ltd & Private \\
\hline & HPCL-Mittal Energy Ltd & Private \\
\hline & Reliance Industries Ltd & Private \\
\hline \multirow{17}{*}{$\begin{array}{l}\text { Power } \\
\text { generation } \\
\& \text { supply }\end{array}$} & NTPC Ltd & Public \\
\hline & Gujarat Industries Power Company Ltd & Public \\
\hline & NHPC Ltd & Public \\
\hline & NLC India Ltd & Public \\
\hline & Power Grid Corp. of India Ltd & Public \\
\hline & SJVN Ltd & Public \\
\hline & Adani Power Ltd & Private \\
\hline & CESC Ltd & Private \\
\hline & Jaiprakash Power Ventures Ltd & Private \\
\hline & JSW Energy Ltd & Private \\
\hline & RattanIndia Power Ltd & Private \\
\hline & Reliance Infrastructure Ltd & Private \\
\hline & Reliance Power Ltd & Private \\
\hline & Schneider Electric Infrastructure Ltd & Private \\
\hline & Suzlon Energy Ltd & Private \\
\hline & Tata Power Company Ltd & Private \\
\hline & Torrent Power Ltd & Private \\
\hline
\end{tabular}

Indian Metals \& Ferro Alloys Ltd 


\section{REFERENCES}

1. Ahluwalia, I. J., 1995. New economic policies, enterprises, and privatization in India. In: R. Cassen and V. Joshi, eds. India: The Future of Economic Reform. Delhi: Oxford University Press.

2. Ahuja, G. and Majumdar, S. K., 1998. An assessment of the performance of Indian state-owned enterprises. Journal of Productivity Analysis, 9(2), pp. 113-132. https://doi.org/10.1023/A:1018352415813

3. Alchian, A. A., 1965. Some economics of property rights. Il politico, pp. 816-829.

4. Banker, R. D., Charnes, A. and Cooper, W. W., 1984. Some models for estimating technical and scale inefficiencies in data envelopment analysis. Management science, 30(9), pp. 1078-1092. https://doi.org/10.1287/mnsc.30.9.1078

5. Bartel, A. P. and Harrison, A. E., 2005. Ownership versus environment: Disentangling the sources of public-sector inefficiency. Review of Economics and Statistics, 87(1), pp. 135-147. https://doi.org/10.1162/0034653053327595

6. Bhaya, H., 1990. Management efficiency in the private and public sectors in India. Public enterprise at the crossroads, pp. 228-240. https://doi.org/ 10.4324/9780203064405.ch15

7. Boardman, A. E. and Vining, A. R., 1989. Ownership and performance in competitive environments: A comparison of the performance of private, mixed, and state-owned enterprises. The Journal of Law and Economics, 32(1), pp. 1-33. https://doi.org/10.1086/467167

8. Boubakri, N. and Cosset, J. C., 1998. The financial and operating performance of newly privatized firms: Evidence from developing countries. The Journal of Finance, 53(3), pp. 1081-1110. https://doi.org/10.1111/0022-1082.00044

9. Caves, D. W. and Christensen, L. R., 1980. The relative efficiency of public and private firms in a competitive environment: the case of Canadian railroads. Journal of political Economy, 88(5), pp. 958-976. https://doi.org/ $10.1086 / 260916$

10. Chames, A., Cooper, W. W. and Rhodes, E., 1978. Measuring the efficiency of decision making units. European journal of operational research, 2(6), pp. 429-444. https://doi.org/10.1016/0377-2217(78)90138-8

11. Dasani, A. P., 2011. Liberalisation, Law and Development. PhD thesis. Rajkot: Saurashtra University.

12. De Alessi, L., 1980. The economics of property rights: A review of the evidence.

13. Dewenter, K. L. and Malatesta, P. H., 2001. State-owned and privately owned firms: An empirical analysis of profitability, leverage, and labor intensity. American Economic Review, 91(1), pp. 320-334. https://doi.org/10.1257/ aer.91.1.320

14. Dholakia, B. H., 1978. Relative performance of public and private manufacturing enterprises in India: total factor productivity approach. Economic and Political Weekly, pp. M4-M11.

15. Dudu, H. and Kilicaslan, Y., 2009. Concentration, profitability and (in) efficiency in large scale firms. In: Productivity, Efficiency, and Economic Growth 
in the Asia-Pacific Region, pp. 39-58. Physica-Verlag HD. https://doi. org/10.1007/978-3-7908-2072-0_3

16. Estrin, S. [et al.], 2009. The effects of privatization and ownership in transition economies. Journal of Economic Literature, 47(3), pp. 699-728. https:// doi.org/10.1257/jel.47.3.699

17. Estrin, S. and Perotin, V., 1991. Does ownership always matter? International Journal of Industrial Organization, 9(1), pp. 55-72. https://doi.org/10.1016/ 0167-7187(91)90005-6

18. Fama, E. F., 1980. Agency problems and the theory of the firm. Journal of political economy, 88(2), pp. 288-307. https://doi.org/10.1086/260866

19. Färe, R., Grosskopf, S. and Logan, J., 1985. The relative performance of publicly-owned and privately-owned electric utilities. Journal of Public Economics, 26(1), pp. 89-106. https://doi.org/10.1016/0047-2727(85)90040-4

20. Frydman, R. [et al.], 1999. When does privatization work? The impact of private ownership on corporate performance in the transition economies. The quarterlyjournal of economics, 114(4), pp. 1153-1191.https://doi.org/10.1162/ 003355399556241

21. Galal, A. [et al.], 1994. Welfare consequences of selling public enterprises: An empirical analysis: a summary. The World Bank. https://doi.org/10.1596/ 0-8213-2976-6

22. Goldeng, E., Grünfeld, L. A. and Benito, G. R., 2008. The performance differential between private and state owned enterprises: The roles of ownership, management and market structure. Journal of Management Studies, 45(7), pp. 1244-1273.

23. Grossman, S. J. and Hart, O. D., 1980. Takeover bids, the free-rider problem, and the theory of the corporation. The Bell Journal of Economics, pp. 42-64. https://doi.org/10.2307/3003400

24. Gupta, M., 1982. Productivity performance of the public and the private sectors in India: A case study of the fertilizer industry. Indian Economic Review, 17(2/4), pp. 165-186.

25. Gupta, N., 2005. Partial privatization and firm performance. The Journal of Finance, 60(2), pp.987-1015.https://doi.org/10.1111/j.1540-6261.2005.00753.x

26. Gupta, S., Jain, P. K. and Yadav, S. S., 2011. Impact of MoU on financial performance of public sector enterprises in India. Journal of Advances in Management Research, 8(2), pp. 263-284. https://doi.org/10.1108/09727981111175984

27. Jain, R., 2017. Public sector enterprise disinvestment in India: Efficiency gains in a political context. Journal of Asian Economics, 53, pp. 18-36. https:// doi.org/10.1016/j.asieco.2017.10.002

28. Kaur, K. and Kumar, S., 2010. Corporate Ownership and the Technical and Scale Efficiency of Pharmaceutical Firms in India-Empirical Evidence. South East European Journal of Economics and Business, 5(2), pp. 95-106. https:// doi.org/10.2478/v10033-010-0019-y 
29. Kreps, D. M. and Wilson, R., 1982. Reputation and imperfect information. Journal of economic theory, 27(2), pp. 253-279. https://doi.org/10.1016/00220531(82)90030-8

30. La Porta, R. and Lopez-de-Silanes, F., 1999. The benefits of privatization: Evidence from Mexico. The Quarterly Journal of Economics, 114(4), pp. 1193-1242. https://doi.org/10.1162/003355399556250

31. Levy, B., 1987. A theory of public enterprise behavior. Journal of Economic Behavior \& Organization, 8(1), pp. 75-96. https://doi.org/10.1016/01672681(87)90022-9

32. Majumdar, S. K., 1998. Assessing comparative efficiency of the state-owned mixed and private sectors in Indian industry. Public Choice, 96(1-2), pp. 1-24. https://doi.org/10.1023/A:1004941023587

33. Manne, H. G., 1965. Mergers and the market for corporate control. Journal of Political economy, 73(2), pp. 110-120. https://doi.org/10.1086/259000

34. Martin, S. and Parker, D., 1997. The impact of privatisation. London: Routledge.

35. Megginson, W. L., 2005. The financial economics of privatization. Oxford: Oxford University Press. https://doi.org/10.1093/0195150627.001.0001

36. Megginson, W. L., Nash, R. C. and Van Randenborgh, M., 1994. The financial and operating performance of newly privatized firms: An international empirical analysis. The Journal of Finance, 49(2), pp. 403-452. https://doi.org/ 10.1111/j.1540-6261.1994.tb05147.x

37. Mijić, K., Jakšić, D. and Berber, N., 2015. The analysis of productivity and profitability in the CEE region: Focus on the private and public sector. Serbian Journal of Management, 10(2), pp. 215-224. https://doi.org/10.5937/sjm10-7426

38. Mohan, T. T. and Ray, S. C., 2003. Technical efficiency in public and private sectors in India: Evidence from the post-reform years.

39. Niskanen, W. A., 1975. Bureaucrats and politicians. The Journal of Law and Economics, 18(3), pp. 617-643. https://doi.org/10.1086/466829

40. Pina, V. and Torres, L., 2006. Public-private efficiency in the delivery of services of general economic interest: The case of urban transport. Local government studies, 32(2), pp. 177-198. https://doi.org/10.1080/03003930600586167

41. Qi, D., Wu, W. and Zhang, H., 2000. Shareholding structure and corporate performance of partially privatized firms: Evidence from listed Chinese companies. Pacific-Basin Finance Journal, 8(5), pp. 587-610. https://doi.org/ 10.1016/S0927-538X(00)00013-5

42. Ramaswamy, K., 2001. Organizational ownership, competitive intensity, and firm performance: An empirical study of the Indian manufacturing sector. Strategic Management Journal, 22(10), pp. 989-998. https://doi.org/10.1002/ smj.204

43. Sarkar, J., Sarkar, S. and Bhaumik, S. K., 1998. Does ownership always matter?-Evidence from the Indian banking industry. Journal of Comparative Economics, 26(2), pp. 262-281. https://doi.org/10.1006/jcec.1998.1516 
44. Shavell, S., 1979. Risk sharing and incentives in the principal and agent relationship. Bell Journal of Economics, 10(1), pp. 55-73. https://doi.org/10.2307/ 3003319

45. Singh, O. and Bansal, S., 2017. An Analysis of Revenue Maximising Efficiency of Public Sector Banks in the Post-Reforms Period. Journal of Central Banking Theory and Practice, 6(1), pp. 111-125. https://doi.org/10.1515/ jcbtp-2017-0006

46. Sufian, F. and Abdul Majid, M. Z., 2008. Bank ownership, characteristics, and performance: A comparative analysis of domestic and foreign Islamic banks in Malaysia. Journal of King Abdulaziz University: Islamic Economics, 21(2). https://doi.org/10.4197/islec.21-2.1

47. Thomsen, S. and Pedersen, T., 1996. Nationality and ownership structures: The 100 largest companies in six European nations. MIR: Management International Review, pp. 149-166.

48. Tichá, M., 2012. State or private ownership? A survey of empirical studies. Review of Economic Perspectives, 12(2), 120-144. https://doi.org/10.2478/ v10135-012-0006-6

49. Tongzon, J. and Heng, W., 2005. Port privatization, efficiency and competitiveness: Some empirical evidence from container ports (terminals). Transportation Research Part A: Policy and Practice, 39(5), pp. 405-424. https:// doi.org/10.1016/j.tra.2005.02.001

50. Williamson, O. E., 1975. Markets and hierarchies: analysis and antitrust implications: a study in the economics of internal organization. University of Illinois at Urbana-Champaign's Academy for Entrepreneurial Leadership Historical Research Reference in Entrepreneurship.

51. Yarrow, G. [et al.], 1986. Privatization in theory and practice. Economic policy, 1(2), pp. 323-364. https://doi.org/10.2307/1344560

52. Zhang, Y. F., Parker, D. and Kirkpatrick, C., 2008. Electricity sector reform in developing countries: an econometric assessment of the effects of privatization, competition and regulation. Journal of Regulatory Economics, 33(2), pp. 159-178. https://doi.org/10.1007/s11149-007-9039-7 